\title{
ISTOTA KOŚCIOŁA I KOLEGIALNOŚCI
}

\section{THE ESSENCE OF THE CHURCH AND OF COLLEGIALITY}

The main topic of this paper is a collegiality in the Church in a Catholic perspective. The main purpose is to describe the essence of collegiality in the Church. The first part of this paper is dedicated to the Church of Christ as a ground of collegiality and drives at describing the essence of the Church. On such basis the second part of this paper discusses the essence of collegiality, both: collegiality of the whole Church and collegiality of the Collegium of the Twelve and its successor - the Collegium of the Bishops. In conclusion the author says that collegiality in the Church is strictly connected to the Church's main attributes: unity, holiness, universality, apostolicity and definitivety. Collegiality in the Church, as all her attributes, is for the Church in the same time a gift and a task, a challenge.

Key words: collegiality, Church, essence of collegiality, essence of the Church.

Obecne czasy charakteryzują się ogromną ilością nieustannie dostarczanych informacji, danych, statystyk, opinii, a także „wiadomości' (smsów, e-maili) krążących w cyberprzestrzeni dzięki nowoczesnym, coraz szybszym i pojemniejszym urządzeniom. Zewsząd płyną niekończące się potoki reklam, porad i wskazówek, często dotyczących prozaicznych, drobnych spraw. W takim „płynnym” świecie coraz bardziej gubi się istota rzeczy i istota ludzkiej egzystencji. Wielu osobom wydaje się, że „nie należą do niczego".

Znamienne są słowa papieża Franciszka: „Dobrze wiem, jak bardzo w naszych czasach szaleją samotność i opuszczenie, szerzy się indywidualizm i wzrasta obojętność wobec losu innych. Miliony mężczyzn i kobiet, dzieci, młodych ludzi gubią się w rzeczywistości, która przysłoniła punkty odniesienia, są zdestabilizowani przez udrękę, że nie należą do 
Te zjawiska dotyczą również świata nauki. W nauce, zarówno w sensie science, jak i humanities, zachodzi szybko postępująca specjalizacja oraz fragmentaryzacja badań i wiedzy, która staje się coraz rozleglejsza, lecz i coraz bardziej szczegółowa do tego stopnia, że sami naukowcy zauważają konieczność jej zespalania w celu zachowania jej sensu i przydatności ${ }^{2}$. Analogiczne procesy zachodzą i w teologii, choć na mniejszą skalę. Jej „przedmiot” jest specyficzny, a przy tym złożony i do końca nieprzenikniony, misteryjny, a w celu jego opisu często stosuje się metodę tzw. wielokrotnego „„”3. Również w teologii pojawia się nagląca potrzeba scalania osiąganych efektów i powracania do istoty rzeczy.

„Do istoty rzeczy”, czyli do czego? Wprawdzie pojęcie „istota” jest wieloznaczne, to jednak jego głównym znaczeniem jest wskazywanie tego, co jest podłożem (przyczyną, warunkiem koniecznym) czegoś, co jest trwałe, niezmienne (co jest substancją, w odróżnieniu od tzw. przypadłości), co jest w czymś najbardziej specyficzne, własne (natura, esencja, indywidualność), co znajduje się wewnątrz czegoś i jest zasłonięte przez warstwę poznawalną empirycznie, co jest sensem czegoś4.

Głównym przedmiotem niniejszego artykułu - świadomie nawiązującego do rosnącej współcześnie konieczności powrotu do istoty rzeczy - będzie kolegialność w Kościele. Można ją właściwie zrozumieć tylko odnosząc ją do jej głębszego podłoża, jej fundamentu, podmiotu, a mianowicie Kościoła. Zasadniczym celem rozważań będzie próba wskazania tego, co najistotniejsze zarówno w Kościele, jak i kolegialności. Strukturę artykułu będą tworzyć dwa punkty. Pierwszy będzie poświęcony istocie Kościoła, drugi - istocie kolegialności, przy czym konieczne tu będzie uwzględnienie zarówno kolegialności całego Kościoła, jak i kolegialności w sensie ścisłym (Kolegium Apostołów i jego sukcesora - Kolegium Biskupów).

niczego. Ich los nie stawia pytań sumieniu wszystkich i często niestety ci, którzy ponoszą największą odpowiedzialność, niewybaczalnie się tłumaczą" (Przemówienie do nowo mianowanych biskupów, 13 IX 2018 r.).

2 A. Lekka-Kowalik, Odkrywanie aksjologicznego wymiaru nauki, Lublin 2008; K. Kaucha, Wiarygodność Kościoła w kontekście wyzwań wspótczesności europejskiej w świetle nauczania Jana Pawta II, Lublin 2008, s. 138-140.

3 H. Seweryniak, Święty Kościót powszedni, Warszawa 1996, s. 57-59.

$4 \quad$ J. Herbut, Istota, [w:] Leksykon Filozofii Klasycznej, red. J. Herbut, Lublin 1997, s. 315316; J. Wojtysiak, Istota, [w:] Dodatek III. Stownik wybranych terminów filozoficznych, [w:] A.B. Stępień, Wstęp do filozofii, Lublin $1995^{3}$, s. 355. 


\section{Istota Kościoła}

Podmiotem kolegialności jest Kościól. Określenie jego istoty jest zadaniem arcytrudnym. Stosunkowo łatwo jest „uchwycić” istotę Kościoła np. w czasie celebracji Eucharystii, w Sakramencie Pokuty i Pojednania, w czasie Światowych Dni Młodzieży czy modlitwy ekumenicznej, natomiast trudno ją adekwatnie opisać. Kościół posiada wiele wymiarów bytu i działalności, wiele „skarbów” niedostępnych poza nim (depozyt i wiarę apostolską, Tradycję, Pismo Święte, Urząd Nauczycielski, sakramenty) i jest dla egzystencji chrześcijańskiej tak ważny, że wszystko w nim może być uznane za istotne.

W tym punkcie zostanie jednak podjęta próba określenia istoty Kościoła, lecz ze świadomością, że nie jest to próba wyczerpująca. Będzie się ona odwoływać głównie, choć nie tylko, do eklezjologicznej twórczości Josepha Ratzingera. Bez wątpienia papieża emeryta Benedykta XVI można nazwać jednym z najwybitniejszych teologów chrześcijańskich, a nawet współczesnym Ojcem Kościoła ${ }^{5}$. Jego geniusz polega m.in. na nieustannym sięganiu do istoty rzeczy i wydobywaniu tego, co jest trwałe. W jednym ze swych tekstów zadaje on pytanie o znaczenie słów „chleba naszego powszedniego” w Modlitwie Pańskiej. Odpowiada, że chodzi tu o "chleb nasz istotny”, czyli o to, co najbardziej potrzebne, wręcz konieczne do życia spełnionego, trwałego, sensownego, prawdziwie chrześcijańskiego, przeżytego w jedności z Bogiem i bliźnimi, do życia wyzwolonego od lęków i egoizmu oraz bezsilnej samotności.

Według Ratzingera Kościół pochodzi od Boga, w jakimś sensie „zawiera” Boga, ponieważ On sam się w nim „zawarł” w sposób definitywny ${ }^{6}$, i łączy ludzkość z Nim. Współczesna eklezjologia katolicka określa naturę (istotę) Kościoła jako złożoną z dwóch zasadniczych elementów: Boskiego i ludzkiego. Jest ona analogiczna do „struktury” osoby Jezusa Chrystusa (Cz.S. Bartnik, M. Rusecki). Kościół jest historyczno-społecznym Wcieleniem Jezusa Chrystusa, tradentem i ciągłą aktualizacją pełni Objawienia Bożego dokonanego

$5 \quad$ H. Seweryniak, Teologiczna droga Josepha Ratzingera - papieża i wspótczesnego Ojca Kościoła, [w:] Niedźwiedź biskupa Korbiniana. W kręgu myśli teologicznej Benedykta XVI, red. H. Seweryniak, K. Sitkowska, P. Artemiuk, Płock 2011, s. 15-74; Teologia fundamentalna w twórczości Josepha Ratzingera, red. K. Kaucha, J. Mastej, Lublin 2017.

6 Joseph Ratzinger często „definiuje” Boga w następujący sposób: „Być nieobjętym przez to, co największe, dać się objąć temu, co najmniejsze, jest rzeczą Boską” (J. Ratzinger, Opera omnia, t. 4: Wprowadzenie do chrześcijaństwa. Wyznanie - Chrzest - Naśladowanie, red. K. Góźdź, M. Górecka, tłum. R. Biel, M. Górecka, Lublin: 2017, s. 135); „Najwyższe wzniesienie się człowieka dokonuje się nie inaczej jak przez zstąpienie Boga. Wina filozofów polega na tym, że nie chcą się poddać temu porządkowi” (J. Ratzinger, Opera omnia, t. 1: Lud i dom Boży w nauce św. Augustyna o Kościele. Rozprawa doktorska oraz inne opracowania nauki Augustyna i teologii Ojców Kościoła, red. K. Góźdź, M. Górecka, tłum. W. Szymona, Lublin 2014, s. 295). 
w Nim (M. Rusecki ), źródłem poznania „istoty” Jezusa Chrystusa i - co za tym idzie - definitywnej prawdy o Bogu (J. Ratzinger), historycznym uwiarygodnieniem Jezusa Chrystusa (A. Dulles ${ }^{8}$ ), Jego Znakiem (A. Dulles, M. Rusecki), ostatnim etapem historii Zbawienia (S. Pié-Ninot ${ }^{9}$, M. Rusecki) oraz wspólnotą Osób Boskich i ludzkich (communio personarum - K. Wojtyła/Jan Paweł II, M. Rusecki ${ }^{10}$ ).

Joseph Ratzinger uważa, że słowem najlepiej wyrażającym istotę Kościoła jest Ekklesia ${ }^{11}$. Ono, wraz ze wszystkimi swymi biblijnymi odniesieniami, jest rdzeniem całej eklezjologii. Jego wyjątkowe znaczenie wynika z tego, że zostało świadomie wybrane przez pierwszych uczniów Jezusa w okresie popaschalnym jako nazwa wyrażająca zarówno ich tożsamość, jak i mesjańsko-eklezjotwórczą samoświadomość Jezusa, której byli świadkami. Rdzeniem (istotą) Kościoła jest to, że jest on w całości tworzony przez Zmartwychwstałego i żyjącego Pana ${ }^{12}$. Według Ratzingera klasyczne eklezjologiczne nazwy czy obrazy Kościoła, jak Ciało Chrystusa i Świątynia Ducha Świętego, treściowo pochodzą od słowa Ekklesia i są jego rozwinięciami. Znaczenie tych obrazów jest nowe i oryginalne, dlatego ten teolog zwracał uwagę na dość powszechny błąd przewijający się w eklezjologii, a mianowicie stwierdzenie, że św. Paweł Apostoł tylko odniósł do Kościoła powszechną w jego czasach alegorię stosowaną przez stoików, którzy traktowali społeczność jako jedno ciało ${ }^{13}$.

Eklezja nie jest społecznością naturalną, lecz nadprzyrodzoną, jest Ciałem Pana $^{14}$. Ono jest permanentnie budowane przez Jezusa Chrystusa jako Jego

7 M. Rusecki, Traktat o Objawieniu, Kraków 2007; tenże, Traktat o Kościele, red. K. Kaucha, P. Królikowski, J. Mastej, Lublin 2015.

A. Dulles, Models of the Church, New York $1987^{2}$.

S. Pié-Ninot, Kościót jako ostatni etap historii zbawienia, [w:] Chrześcijaństwo jutra. Materiały II Międzynarodowego Kongresu Teologii Fundamentalnej (Lublin, 18-21 IX 2001), red. M. Rusecki i in., Lublin 2001, s. 404-443.

10 M. Rusecki, Teologiczny personalizm społeczny Jana Pawła II, [w:] Personalizm polski, red. M. Rusecki, Lublin 2008 („Biblioteka Teologii Fundamentalnej” t. 3), s. 429-440.

11 K. Kaucha, Inspiracje twórczościJosepha Ratzingera dla teologiifundamentalnej, [w:] Teologia fundamentalna w twórczości Josepha Ratzingera, s. 292-294.

12 „Kościoła nie należy więc definiować, wychodząc od jego urzędów i jego organizacji, ale wychodząc od jego służby Bożej: jako wspólnotę stołu wokół Zmartwychwstałego, który wszystkich zewsząd gromadzi i jednoczy" (J. Ratzinger, Opera omnia, t. 4, s. 264).

13 „Wielkim błędem jest stale powtarzane twierdzenie, że Paweł tylko odniósł do Kościoła alegorię rozpowszechnioną w jego czasach w filozofii stoickiej” (J. Ratzinger,.Opera omnia, t. 8/1: Kościót - znak wśród narodów. Pisma eklezjologiczne i ekumeniczne, red. K. Góźdź, M. Górecka, tłum. W. Szymona, Lublin 2013, s. 213).

14 K. Góźdź, Istota Kościoła wedlug Josepha Ratzingera, [w:] Teologia fundamentalna w twórczości Josepha Ratzingera, s. 191-201. 
Ciało zarówno „od dołu”, pierwotnego fundamentu, jak i „od góry”, swego ostatecznego celu i istoty ${ }^{15}$. To Ciało - według Ratzingera - jest nową ludzkością, która jest tworzona przez Jezusa Chrystusa jako „nowego Adama” i złączona z Nim tak, jak cała ludzkość pochodzi od pierwszego Adama niosąc w sobie zarówno jego godność, jak i słabości. Podłożem tej myśli jest dla Ratzingera biblijna idea Adama i Jezusa nowego Adama jako tzw. ludzi gatunkowych, kolektywnych i „osobowości korporacyjne”, czyli osoby zawierające w sobie wszystkich swoich potomków ${ }^{16}$.

W świetle myśli Ratzingera Eklezja jest Ciałem, nowym i definitywnym istnieniem o charakterze religijno-społecznym, w którym istotna jest zarówno misteryjność, jak i realność. Kościól nie jest ideą lub ideałem, który dopiero trzeba by realizować, ani utopią, może piękną i słuszną, lecz niemożliwą do ucieleśnienia. Eklezja jest, istnieje, jest faktem, dlatego trafnie określa się ją jako Ciało (Corpus). Tu Ratzinger dodaje jednak, że w dziejach eklezjologii, niezbyt szczęśliwie, dokonała się zamiana desygnatów pojęć corpus mysticum i corpus verum, co skutkowało zapomnieniem o realności Kościoła. Na podstawie badań $\mathrm{H}$. de Lubaca Ratzinger stwierdza, że w starożytności i wczesnym średniowieczu przez corpus verum (prawdziwe ciało) rozumiano właśnie Kościól, a przez corpus mysticum (mistyczne ciało sakramentalne) - Eucharystię, lecz później te desygnaty zostały zamienione ${ }^{17}$.

Jednym z najważniejszych rysów istoty Eklezji jest, według Ratzingera, paschalność i związana z nią wolność - „[...] pascha przechodzenia od sposobu życia tego świata do życia w nowości Ducha, nadal jest jego [Kościoła - przyp. K.K.] żywym, podstawowym prawem: tajemnica wielkanocna jest stałą formą kościelnej egzystencji w tym świecie" ${ }^{18}$. Fundamentalne dla Kościoła i w Kościele prawo paschalne otwiera mu drogę do wolności w najważniejszym sensie

15 J. Ratzinger przypomina myśl biblijną i Ojców Kościoła, że fundament budowli już ją w sobie całą zawiera, przenika, determinuje i wskazuje na jej cel - Christus Fundamentum et Caput (J. Ratzinger, Opera omnia, t. 1, s. 313-317).

16 J. Ratzinger przywołuje badania na ten temat podjęte przez Johannesa Pedersena i Henry'ego Wheelera (J. Ratzinger, Opera omnia, t. 8/1, s. 134). Stwierdza, że „osobowość korporacyjną” w przypadku Adama należy rozumieć, że „jesteśmy wszyscy Adamem jednym człowiekiem" (tamże, s. 214).

17 „Henri de Lubac po bardzo dokładnym przebadaniu tej kwestii wykazał nadto, że określenia te w chrześcijańskiej starożytności i we wczesnym średniowieczu były używane odwrotnie niż w naszych czasach. Przez corpus verum (prawdziwe ciało) rozumiano Kościół, a przez corpus mysticum (mistyczne ciało sakramentalne) - Eucharystię" (J. Ratzinger, Opera omnia, t. 8/1, s. 136).

18 Tamże, s. 423. Zob. J. Mastej, Paschalna wiarygodność chrześcijaństwa i Kościoła wedtug Josepha Ratzingera/Benedykta XVI, [w:] Teologia fundamentalna w twórczości Josepha Ratzingera, s. 135-151. 
tego słowa - wolności rozumianej jako „uczestnictwo w bycie Bożym”, do którego nie ma przystępu poza Kościołem jako Ciałem Pana ${ }^{19}$. Poza nim nie ma też Equangelii o Zmartwychwstaniu Jezusa, a właśnie ono otworzyło ludzkości nowy wymiar bytowania - bytowanie z Bogiem, którego nic nie ogranicza.

Według Ratzingera istotę Eklezji określają także jej przymioty zawarte już w najstarszych symbolach wiary, a mianowicie jedność, świętość, powszechność i apostolskość. One wszystkie, jak i cały Kościól, pochodzą od Boga, są Jego darem, „zawierają” Jego Byt i umożliwiają członkom Ciała Pana uczestnictwo w Bożym bytowaniu. Ratzinger uważa, że należy wyeksponować także definitywność Kościoła, którą rozumie jako ostateczność, absolutność i pełnię. Eklezja zawdzięcza swą definitywność pełni i ostateczności objawienia Jezusa Chrystusa. Jest ono pełne i ostateczne, ponieważ takie przymioty posiada jego autor - Jezus Chrystus, Syn Ojca.

Te treści są myślą przewodnią deklaracji Dominus Iesus o jedyności i powszechności zbawczej Jezusa Chrystusa i Kościoła, która została opublikowana przez Kongregację Nauki Wiary, gdy Ratzinger był jej prefektem ${ }^{20}$. Zwraca się w niej uwagę i na to, że Kościół cieszy się przymiotem jedności dlatego, ponieważ odznacza się jedynością ${ }^{21}$. Jeden Kościół Chrystusowy nadal trwa w całej pełni w Kościele katolickim - głosi ta deklaracja nawiązując do nauczania Vaticanum II - dzięki sukcesji prymatu i apostolatu oraz „właściwej i całkowitej rzeczywistości eucharystycznego misterium"22. Ratzinger w swych tekstach eklezjologicznych i ekumenicznych często przywoływał tzw. listy komunijne w starożytności, zwane litterae communicatoriae, tesserae, symbola, litterae pacis, jako historycznie poświadczające troskę Kościoła o jedność i jedyność, które były rozumiane jako filary tożsamości (istoty) i prawdziwości Eklezji ${ }^{23}$.

Należy także przypomnieć krytyczne uwagi Ratzingera dotyczące niewłaściwego rozumienia Kościoła i jego istoty, które miały miejsce w przeszłości i ma obecnie, a które są ważne także dla następnego punktu rozważań. Pisał on: „Otóż utożsamianie »Kościoła z z samą hierarchią ( z papieżem i biskupem) jest błędem; jeszcze większym błędem jest utożsamianie «Kościoła» z kościelną

19 „W Kościele chodzi o wolność w najgłębszym sensie tego słowa, o możność uczestnictwa w bycie Bożym” (J. Ratzinger, Opera omnia, t. 8/1, s. 408). Mówiąc o wolności warto przytoczyć inną wypowiedź tego autora: „Pozór przytłacza byt. Pozór staje się wszechwładnym kryterium. Człowiek żyje dla pozoru, dlatego też jego życie staje się życiem pozornym. Biblia słusznie widzi w tym szczyt zniewolenia i braku wolności” (tamże, s. 406).

20 Kongregacja Nauki Wiary, Deklaracja Dominus Iesus o jedyności i powszechności zbawczej Jezusa Chrystusa i Kościoła, Rzym 2000, nr 5-8.

21 Tamże, nr 16-17.

22 Tamże, nr 17.

23 J. Ratzinger, Opera omnia, t. 8/1 s. 141, 484-485. 
biurokracją [...]”24 oraz „Yves Congar wskazał na to, że katolicyzm jest dzisiaj pojmowany przede wszystkim jako jedność wokół hierarchii, a zwłaszcza wokół Papieża, gdy tymczasem dawniej oznaczał on również jedność między Kościołami, wzajemną jedność wspólnot”" ${ }^{25}$. Ratzinger, jak wielu innych teologów zwłaszcza doby soborowej i posoborowej, krytykował tzw. instytucjonalną koncepcję Kościoła. W Polsce czynił to m.in. ks. M. Rusecki. Uważał on, że Kościoła jako tylko instytucji nie ma. W prawdzie posiada on wymiar instytucjonalny, który jest ważny, lecz jest on podporządkowany komunijności Eklezji. Pisał też o niepokojącym zjawisku auto-ekskomunikowania się z Kościoła. Polega ono na tym, że wierni świeccy utożsamiając Kościól z duchowieństwem praktycznie umieszczają siebie poza Eklezją. Ratzinger, analizując zagadnienie chrześcijańskiego braterstwa ${ }^{26}$, zwracał też uwagę na zawężanie w przeszłości pojęć „brat” i „braterstwo” tylko do przedstawicieli kleru i towarzyszące temu ich myślenie, że są oni „właściwymi przedstawicielami życia kościelnego”27. Można powiedzieć, że jest to inny rodzaj auto-ekskomunikowania się z Eklezji niż ten, o którym pisał ks. Rusecki.

Na zakończenie tego punktu rozważań, stanowiącego introdukcję do następnego, należy stwierdzić, że istnieje uprzednia wobec Kościoła rzeczywistość będąca jego fundamentem i wyznaczająca jego istotę. Jest nią zainicjowanie nowego istnienia w Synu Bożym i jest to dar Boga. Nowe istnienie może otworzyć tylko Bóg. Zaczyna ono przemieniać człowieka i świat tylko wtedy, gdy człowiek przyjmie je jako dar ${ }^{28}$. Jest ono podłożem całego Kościoła, a co za tym idzie, także wszystkich jego istotnych właściwości i urzeczywistnień, do których należy również kolegialność.

\section{Istota kolegialności}

Eklezjologia II Soboru Watykańskiego charakteryzuje się m.in. wyeksponowaniem zagadnienia kolegialności w jego dwóch, ściśle zespolonych ze sobą znaczeniach: jako istotna cecha (charakter, natura) całego Kościoła oraz jako istotna cecha Kolegium Biskupów będącego sukcesorem Kolegium

Tamże, s. 448 .

J. Ratzinger, Opera omnia, t. 1, s. 598.

Tamże, s. 568-603.

Tamże, s. 584.

28 „Na pierwszym planie nie stoi zgrupowanie ludzi, czyli Kościół, tylko dar Boży, który człowieka zwraca ku nowemu istnieniu, jakiego sam sobie dać nie może, ku wspólnocie, którą może przyjąć tylko jako dar" (J. Ratzinger, Opera omnia, t. 4, s. 265). 
Apostołów ${ }^{29}$. Pomijanie pierwszego znaczenia kolegialności i utożsamianie jej tylko z kolegialnością Kolegium Biskupów jest błędem. Nie jest istotne, od którego znaczenia kolegialności rozpoczyna się jej charakterystykę, lecz to, by uwzględnić obydwa, a także ich uzasadnienie oraz ścisłe zespolenie. W tym punkcie artykułu najpierw zostanie omówiona się kolegialność całego Kościoła.

\section{Kolegialność całego Kościoła}

Wydaje się oczywiste, że skoro Kościól jest Ciałem Pana, to wszyscy jego członkowie tworzą jedno Ciało i wszyscy są zespoleni z Jego Głową, Jezusem Chrystusem. Sakrament Chrztu i wymagana do jego udzielenia wiara czyni człowieka członkiem Ciała równym w tej godności wszystkim innym członkom $^{30}$. „Jeden jest wasz Nauczyciel, a wy wszyscy braćmi jesteście” (Mt 23, 8). Słuchający słów Boga i wypełniający je są dla Jezusa „bratem, siostrą i matką” (Mt 12, 50), są Jego najbliższą rodziną. Wszyscy w Kościele są obdarowani „po równo" tym samym zaproszeniem do wiary, darem Objawienia Bożego, tym samym powołaniem do komunii z Bogiem i tym samym celem - służeniem Królestwu Bożemu i zaprowadzaniem go w świecie w imię Pana i wraz z Nim. Członkostwo w Kościele nie daje nikomu żadnego powodu do „chlubienia się” czy wywyższania ponad kimkolwiek, zarówno będącym w Kościele, jak i niebędącym w nim. To jest integralna część chrześcijańskiej wiary. Akcentuje ona także, że wszyscy ludzie są równi sobie w człowieczeństwie, czyli przynależności do rodzaju ludzkiego, ludzkości, jednej ludzkiej rodziny. Personalistyczna norma moralna, charakteryzująca etykę chrześcijańską, nakazuje szacunek i miłość do każdego człowieka, bez względu na jakiekolwiek różnice. Jeśli można mówić, na podstawie Equangelii Jezusa, o jakimkolwiek wyróżnianiu się w Kościele, to tylko poprzez służbę (,Jeśli kto chce być pierwszym, niech będzie ostatnim ze wszystkich i sługą wszystkich!” - Łk 9, 35b). Ten jednak, kto służy, nigdy nie myśli o wywyższaniu się.

Ksiądz M. Rusecki, analizując eklezjalną kolegialność z perspektywy eklezjologii fundamentalnej, traktuje ją jako jeden ze znaków wiarygodności Kościoła. W jednym znaku, a mianowicie „Kolegium Apostolskiego i kolegialności

29 J. Ratzinger. Opera omnia, t. 7/2: O nauczaniu II Soboru Watykańskiego. Formułowanie Przekaz - Interpretacja, red. K. Góźdź, M. Górecka, tłum. E. Grzesiuk, Lublin 2016.

30 „Oczywiście ci, którzy sprawują władzę nauczycielską, mianowicie papież i biskupi, są przede wszystkim ochrzczonymi członkami Ludu Bożego, z czego wynika ich uczestnictwo w sensus fidelium” (Międzynarodowa Komisja Teologiczna, „Sensus fidei” w życiu Kościoła, Kraków 2015, nr 76, s. 78; szerzej na temat związku sensus fidei z Urzędem Nauczycielskim Kościoła zob. tamże, nr 74-80). 
Kościoła”, ujmuje oba wspomniane już znaczenia kolegialności i spaja je ${ }^{31}$. W swym nowatorskim katalogu ${ }^{32}$ znaków wiarygodności Kościoła umieszcza go na drugim miejsce, tuż po znaku Piotra. Pisze o kolegialności całego Kościoła, która osadzona jest na równości wszystkich członków Ludu Bożego, choć pełnią oni różne funkcje w Ciele Pana. Zwraca uwagę na to, że wprawdzie trzy podstawowe posługi w Kościele - nauczania, uświęcania i pasterzowania - zostały powierzone przede wszystkim Apostołom i ich następcom, to powinny być one wykonywane z udziałem wiernych świeckich. Dotyczy to nie tylko dwóch pierwszych posług, lecz także trzeciej ${ }^{33}$. Na kanwie tego teolog ten wielokrotnie pisał o tzw. kolegialności „w dół”, czyli współpracy, współodpowiedzialności oraz współdziałaniu hierarchii i wiernych świeckich na wszystkich szczeblach struktur kościelnych. Czynił z tego postulat pod adresem Kościoła w Polsce, w którym - jego zdaniem - kolegialności „w dół” brakuje, wskutek czego można obserwować zjawisko auto-ekskomunikowania się niektórych wiernych świeckich (i też duchownych) z Kościoła.

Ksiądz Z. Krzyszowski pisząc o kolegialności w Kościele ${ }^{34}$ sięga daleko w jego dzieje. Według niego jako pierwszy użył tego terminu św. Ignacy Antiocheński w Liście do Magnezjan $(7,1)$ w odniesieniu do prezbiterium nazywanego przez Ignacego duchowym klejnotem Kościoła zgadzającym się ze swoim biskupem ${ }^{35}$. Ksiądz Z. Krzyszowski przywołuje też następujące słowa św. Cypriana: „od progu mojego Episkopatu przyjąłem zasadę nie decydować o niczym sam, bez waszej - kapłanów i diakonów - rady oraz bez poparcia mojego ludu” (Epistula 14, 4); „szczególne przypadki winienem poznać i przestudiować starannie sposób ich rozwiązania nie tylko z moimi kolegami, ale także z całym ludem" (Epistula 34, 4, 1) ${ }^{36}$.

Istotą kolegialności w całym Kościele jest on sam jako dzieło Jezusa Chrystusa i Jego Ciało obejmujące wszystkie członki. Można powiedzieć, że jest ona czymś więcej niż znak wiarygodności Eklezji. Jest jedną z jej istotnych cech i właściwości jej natury, bytu, powiązaną z jednością, świętością, powszechnością, apostolskością i definitywnością Kościoła, a także przykazaniem miłości

31 M. Rusecki, K. Kaucha, A. Pietrzak, Znaki wiarygodności Kościoła, [w:] Leksykon Teologii Fundamentalnej, red. M. Rusecki i in., Lublin - Kraków 2002, s. 1382-1383.

32 Tamże, s. 1381-1393.

33 „W ramach pasterskiej funkcji w Kościele winna dokonywać się daleko idąca współpraca duchownych ze świeckimi, i to na wszystkich szczeblach życia religijno-moralnego; dzięki temu może się realizować idea kolegializmu i wspólnoty już na terenie parafii” (tamże, s. 1383).

Z. Krzyszowski, Kolegializm, [w:] Leksykon Teologii Fundamentalnej, s. 629-634.

Tamże, s. 630.

Tamże, s. 633. 
jako wyróżnikiem chrześcijaństwa. Kościól, jak często przypominał J. Ratzinger, to nowa ludzkość zwołana przez "nowego Adama”. Idąc za tymi słowami można powiedzieć, że Eklezja to nie tylko społeczność uczniów Jezusa Chrystusa, lecz kolegium jego uczniów, którzy są współodpowiedzialni za życie Ewangelią, siebie nawzajem, wszystkich bliźnich i cały świat. Kolegialność w Kościele oznacza, że nie ma w nim żadnych podziałów: ani kastowych, ani politycznych, ani ze względu na zamożność czy wiedzę. Podziały zostały zniesione przez zbawcze i kościołotwórcze dzieło Jezusa Chrystusa, który pojednał nas z Ojcem i zarazem nas ze sobą. Święty Paweł Apostoł pisząc o zniesieniu w Kościele jakichkolwiek różnic między ludźmi („Nie ma już Żyda ani poganina, nie ma już niewolnika ani człowieka wolnego, nie ma już mężczyzny ani kobiety, wszyscy bowiem jesteście kimś jednym w Chrystusie Jezusie" - Ga 3, 28), wskazał tym samym na podłoże i istotę kolegialności całego Kościoła.

\section{Kolegialność Kolegium Biskupów}

Eklezjologia katolicka dużą wagę przywiązuje do tzw. struktury Kościoła, zwłaszcza prymatu i Episkopatu. Katolicka eklezjologia fundamentalna do dziś ujmuje trwanie prymatu i Episkopatu jako jeden z zasadniczych argumentów za wiarygodnością i prawdziwością Kościoła katolickiego ${ }^{37}$. O ile do Vaticanum II ta eklezjologia uwypuklała genezę i uzasadnienie (biblijne, historyczne, w Tradycji i nauczaniu Kościoła) sukcesji prymatu i Episkopatu, o tyle od ostatniego soboru zaczęła reflektować także nad teologicznym znaczeniem tych podstawowych struktur Eklezji. Kanonistów, co oczywiste, interesują przede wszystkim prawne regulacje funkcjonowania tych urzędów, teologów natomiast geneza, istota, cel i zadania oraz właściwy kształt ich sprawowania w Kościele i dla jego dobra.

W eklezjologii katolickiej kolegialność (lub kolegializm) jest najczęściej wiązana właśnie z Kolegium Biskupów. Jest definiowana jako wewnętrzna struktura, charakter i natura Episkopatu ściśle związanego z prymatem Biskupa Rzymu oraz podstawowy sposób funkcjonowania tego Kolegium, które jest podmiotem najwyższej i pełnej władzy w całym Kościele (KK 22; KPK 330, KKK 880) ${ }^{38}$. Kolegium Biskupów to następca (sukcesor) Dwunastu, czyli Kolegium Apostołów z Piotrem na czele. Kolegialność oznacza, że, jak Dwunastu, tak Kolegium Biskupów stanowi jedność i ją zachowuje w działaniu. Chodzi o współdziałanie, współodpowiedzialność i jedność biskupów z Papieżem (cum

\footnotetext{
37 S. Nagy, Chrystus w Kościele. Zarys eklezjologii fundamentalnej, Wrocław 1982; M. Żmudziński, Teologia prymatu w myśli eklezjologiczno-ekumenicznej kardynała Stanisława Nagyego, „Roczniki Teologiczne” 2018, 65, z. 9, s. 91-106.

38 Z. Krzyszowski, Kolegializm, [w:] Leksykon Teologii Fundamentalnej, s. 630.
} 
Petro et sub Petro) oraz między sobą, a także ich wspólną troskę o wszystkie Kościoły lokalne. Istnieje collegialitas effectiva, czyli współpraca i wspólne działanie Kolegium przy pomocy konkretnych narzędzi, oraz collegialitas affectiva oznaczająca braterstwo, poczucie wspólnoty, łączności, jedności, miłości i pokoju spajające Kolegium.

Biblijną podstawą kolegialności biskupów są teksty opisujące genezę, misję i działalność Dwunastu z Piotrem na czele. Znajdują się one we wszystkich księgach Nowego Testamentu. Dwunastu kolegialnie kierowało życiem młodego Kościoła podejmując ważne decyzje doktrynalno-liturgiczne i organizacyjne (wybór Macieja, powołanie diakonów, zwołanie tzw. Soboru Jerozolimskiego) oraz w zakresie dóbr materialnych ${ }^{39}$. Ksiądz Z. Krzyszowski opisał dziejowy rozwój idei kolegialności biskupiej ${ }^{40}$. Jako pierwszy terminu collegium użył prawdopodobnie św. Cyprian, który tak właśnie nazwał wspólnotę biskupów dodając jednocześnie, że ich jedność odzwierciedla jedność całego Kościoła (Epistula LXVI 8, 3) ${ }^{41}$. Są to słowa, które trafnie wskazują na istotę kolegialności biskupiej w Kościele.

Sposobami realizacji kolegialności biskupiej są: sobory powszechne, Synody Biskupów, Konsystorze Kardynałów (zwyczajne, nadzwyczajne), Konferencje Episkopatów (kontynentalnych, regionalnych, krajowych), działalność Kurii Rzymskiej, wizyty ad limina (co 5 lat) i pielgrzymki papieskie ${ }^{42}$.

Kolegialność Kolegium Biskupów wynika zarówno z jedności i kolegialności całego Kościoła, jak i ustanowienia Dwunastu przez Jezusa w czasie Jego ziemskiego życia. Kolegium Biskupów jest sukcesorem i aktualizacją misji Dwunastu w Kościele i dla świata. W rozumieniu katolickim jest zarówno cechą wyróżniającą Eklezję (trwałym elementem eklezjalności z ustanowienia Bożego), jak i znakiem jej prawdziwości (autentyczności) oraz wiarygodności.

\section{Zakończenie}

Niniejszy artykuł osadzony został na założeniu, że adekwatna charakterystyka kolegialności Kolegium Biskupów może zostać dokonana tylko wtedy, gdy powiąże się ją z kolegialnością całego Kościoła i wskaże istotę - najgłębsze podłoże, przyczynę, cel i sens. Tą istotą jest Kościól, a jego istotą z kolei nowa egzystencja w Jezusie Chrystusie jako Głowie Ciała (Kościoła) i całej ludzkości. Metoda „istotowa”, którą można też nazwać hermeneutyczną,

\footnotetext{
39 Tamże, s. 629-630.

40 Tamże, s. 630-633.

41 Tamże, s. 630.

42 Tamże, s. 630-633.
} 
stosowana w niniejszych rozważaniach, została zaczerpnięta - wraz z wieloma treściami - z twórczości Josepha Ratzingera. Ten sposób myślenia jest bardzo potrzebny $\mathrm{w}$ dzisiejszych czasach, gdy w chaosie informacji, atmosferze pędu cywilizacji oraz płynności świata trudno ludziom o znalezienie niezmiennych punktów odniesienia i istoty egzystencji. $\mathrm{Z}$ tego powodu w artykule celowo wyeksponowany został Kościół jako trwały „punkt odniesienia” i tradent istoty ludzkiej egzystencji cieszący się przy tym przymiotami jedności, świętości, powszechności, apostolskości, definitywności i kolegialności.

Pozostaje jeszcze zagadnienie praktycznej realizacji czy funkcjonowania tych przymiotów Eklezji, zarówno Kościoła powszechnego, jak i lokalnych. Współczesna eklezjologia katolicka (w Polsce kard. S. Nagy, W. Hryniewicz, M. Rusecki, H. Seweryniak) widzi je jako jednocześnie dar i zadanie. Są one Bożym darem dla Kościoła, który to dar nigdy się nie wyczerpie i zawsze „działa”, gdy zostanie przyjęty ludzką wolnością. Z drugiej strony, być może nigdy nie uda się ich osiągnąć w stu procentach z powodu ludzkich słabości i ograniczeń. $\mathrm{Z}$ tego tytułu są dla Eklezji zadaniem.

Słowa kluczowe: kolegialność, Kościól, istota kolegialności, istota Kościoła.

\section{Bibliografia:}

\section{Nauczanie Kościoła:}

1. Kongregacja Nauki Wiary, Deklaracja „Dominus Iesus” o jedyności i powszechności zbawczej Jezusa Chrystusa i Kościoła. Rzym 2000.

2. Kongregacja Nauki Wiary, Prymat następcy Piotra w tajemnicy Kościoła, [w:] W trosce o petnię wiary. Dokumenty Kongregacji Nauki Wiary 1995-2000, red. J. Królikowski, Z. Zimowski. Tarnów 2002, s. 57-65.

3. Sobór Watykański II, Konstytucja dogmatyczna o Kościele, [w:] Sobór Watykański II, Konstytucje, dekrety, deklaracje, tekst polski, Poznań 1967, s. 127-165.

\section{Inne pozycje:}

1. „Communio” w chrześcijańskiej refleksji o Kościele, red. A. Czaja, M. Marczewski, Lublin 2004.

2. Episcopal Conferences. Historical, Canonical and Theological Studies, red. T.J. Reese, Washington 1989.

3. Góźdź K., Istota Kościota wedlug Josepha Ratzingera, [w:] Teologia fundamentalna w twórczości Josepha Ratzingera, red. K. Kaucha, J. Mastej, Lublin 2017, s. 191-201.

4. Henn W., The honor of my brothers: a short history of the relations between the Pope and the bishops, New York 2000. 
5. Herbut J., Istota, [w:] Leksykon Filozofii Klasycznej, red. J. Herbut, Lublin 1997, s. 315-316.

6. Kaucha K., Inspiracje twórczości Josepha Ratzingera dla teologii fundamentalnej, [w:] Teologia fundamentalna w twórczości Josepha Ratzingera, red. K. Kaucha, J. Mastej, Lublin 2017, s. 292-294.

7. Kaucha K., Wiarygodność Kościoła w kontekście wyzwań wspótczesności europejskiej w świetle nauczania Jana Pawta II, Lublin 2008.

8. Krzyszowski Z., Kolegializm, [w:] Leksykon Teologii Fundamentalnej, red. M. Rusecki i in., Lublin - Kraków 2002, s. 629-634.

9. Krzywda J., Prymat papieski i Kolegium Biskupów w świetle nauki Vaticanum I i II, Kraków 2008.

10. Mastej J., Paschalna wiarygodność chrześcijaństwa i Kościoła wedlug Josepha Ratzingera/Benedykta XVI, [w:] Teologia fundamentalna w twórczości Josepha Ratzingera, red. K. Kaucha, J. Mastej, Lublin, s. 135-151.

11. Nagy S., Chrystus w Kościele. Zarys eklezjologii fundamentalnej, Wrocław 1982.

12. Nagy S., Hierarchia kościelna, [w:] Leksykon Teologii Fundamentalnej, red. M. Rusecki i in., Lublin - Kraków 2002, s. 486-488.

13. Nagy S., Soborowa nauka o kolegialności władzy w Kościele, [w:] Idee przewodnie soborowej konstytucji o Kościele, red. S. Grzybek, Kraków 1971, s. 219-240.

14. Nagy S., Zuberbier A, Dlaczego kolegializm?, „Znak” 1964, 16, nr 9 (123), s. 1092-1113.

15. Quinn J. R., Ever Ancient, Ever New. Structures and Communion in the Church, New York 2013.

16. Ratzinger J., Opera omnia, t. 1: Lud i dom Boży w nauce św. Augustyna o Kościele. Rozprawa doktorska oraz inne opracowania nauki Augustyna i teologii Ojców Kościoła, red. K. Góźdź, M. Górecka, tłum. W. Szymona, Lublin 2014.

17. Ratzinger J., Opera omnia, t. 4: Wprowadzenie do chrześcijaństwa. Wyznanie Chrzest - Naśladowanie, red. K. Góźdź, M. Górecka, tłum. R. Biel, M. Górecka, Lublin 2017.

18. Ratzinger J., Opera omnia, t. 7/2: O nauczaniu II Soboru Watykańskiego. Formutowanie - Przekaz - Interpretacja, red. K. Góźdź, M. Górecka, tłum. E. Grzesiuk, Lublin 2016.

19. Ratzinger J., Opera omnia, t. 8/1: Kościót - znak wśród narodów. Pisma eklezjologiczne i ekumeniczne, red. K. Góźdź, M. Górecka, tłum. W. Szymona, Lublin 2013.

20. Rusecki M., Traktat o Kościele, red. K. Kaucha, P. Królikowski, J. Mastej, Lublin 2015.

21. Rusecki M., Kaucha K., Pietrzak A., Znaki wiarygodności Kościoła, [w:] Leksykon Teologii Fundamentalnej, red. M. Rusecki i in, Lublin - Kraków 2002, s. 1381-1393.

22. Sensus fidei w życiu Kościoła, Międzynarodowa Komisja Teologiczna, Kraków 2015.

23. Seweryniak H., Święty Kościót powszedni, Warszawa 1996.

24. Seweryniak H., Teologiczna droga Josepha Ratzingera - papieża i wspótczesnego Ojca Kościoła, [w:] Niedźwiedź biskupa Korbiniana. W kręgu myśli teologicznej Benedykta XVI, red. H. Seweryniak, K. Sitkowska, P. Artemiuk, Płock 2011, s. 15-74.

25. Teologia fundamentalna w twórczości Josepha Ratzingera, red. K. Kaucha, J. Mastej, Lublin 2017. 
26. Wąsek D., Nowa wizja zarzadzania Kościołem, Kraków 2014.

27. Wojtysiak J., Istota, Dodatek III. Stownik wybranych terminów filozoficznych, [w:] A. B. Stępień, Wstęp do filozofii, Lublin $1995^{3}$, s. 355.

28. Żmudziński M., Teologia prymatu w myśli eklezjologiczno-ekumenicznej kardynała Stanistawa Nagyego, „Roczniki Teologiczne” 2018, 65, z. 9, s. 91-106. 